\title{
Jolanta Tambor, Mowa Górnoślazaków oraz ich świadomość językowa i etniczna, wyd. 2, Wydawnictwo Uniwersytetu Śląskiego, Katowice 2008, ss. 316
}

Problematyka podjęta w drugim wydaniu gruntownego opracowania traktującego o śląskim języku regionalnym nawiązuje do popularnej w ostatnich czasach swoistej mody na regionalność, której przejawem jest między innymi zainteresowanie miejscowymi odmianami językowymi. Autorka, Jolanta Tambor, przedstawia temat z bardzo szerokiej perspektywy - nie tylko stricte językoznawczej. Opisuje powiązane z językiem i mające na niego znaczący wpływ szczególnie w przypadku Śląska - fakty polityczne, społeczne oraz kulturalne. Tym samym recenzowana praca stanowi kompleksowe i wszechstronne dzieło naukowe, jedyne w swoim rodzaju, jeśli chodzi o ciekawe zagadnienie, jakim jest język mieszkańców ziem śląskich. Można je uznać za szczególnie rzetelne, ponieważ, jak podkreśla autorka we wstępie, napisała je osoba związana emocjonalnie z przedmiotem badań. Może to oczywiście stanowić przeszkodę, zaprzeczać obiektywizmowi pracy o charakterze naukowym, ale w przypadku tak skomplikowanej materii, jaką jest gwara, wypada zgodzić się z twierdzeniem, iż wywodzenie się z danego środowiska językowego „daje możliwość natychmiastowej konfrontacji zbieranego materiału i jego oceny” (s. 119).

Badania oparto na bogatej i różnorodnej bazie materiałowej, zgromadzonej w latach 90. XX wieku oraz w pierwszym dziesięcioleciu XXI wieku. Składały się na nią po pierwsze: nagrania audio i wideo spontanicznych rozmów z użytkownikami języka (odpowiednio dobranymi - ze względu na ich akceptację śląskości i faktyczną znajomość kultury i języka) oraz różnego rodzaju programów telewizyjnych o charakterze folklorystycznym, po drugie: wyniki ankiet i wywiadów kwestionariuszowych, po trzecie: materiały pisane, czyli książki i artykuły z opowieściami, wywiadami, a także godkami, berami (anegdotami) i wicami (dowcipami). 
Celem recenzowanej pracy, jak wskazuje tytuł, jest opis trzech zasadniczych zagadnień związanych z językiem Śląska. Autorka pragnie mianowicie przedstawić: „dzisiejsze faktyczne procesy społeczne, kulturalne i polityczne oraz ich rezultaty na Górnym Śląsku, ze szczególnym uwzględnieniem stanu języka”, „stan świadomości użytkowników badanej regionalnej odmiany języka w wyniku dotarcia do różnych przejawów owej świadomości, zarówno do świadomości narodowej/etnicznej, jak i do świadomości językowej” oraz kwestię według autorki najważniejszą - „uchwycenie wzajemnych relacji między stanem faktycznym uzusu językowego a świadomością użytkowników" (s. 9-10). Wszystkie te tematy są kwestiami skomplikowanymi i wymagały zazwyczaj obszernego wprowadzenia z zakresu socjologii lub socjolingwistyki.

Na publikację składają się zatem trzy rozdziały. W części pierwszej - Język i identyfikacja. Świadomość etniczna mieszkańców Górnego Ślqska (s. 15-67) - przedstawiono podstawowe pojęcia potrzebne do dookreślenia grupy stanowiącej źródło informacji do badań, takie jak: naród, narodowość, tożsamość, identyfikacja. Są one punktem wyjścia do rozważań na temat statusu języka śląskiego i jego roli w kształtowaniu się postaw autonomistycznych. Na ich podstawie autorka formułuje wnioski dotyczące poczucia śląskości, które to kwestie nierozłącznie wiążą się z zagadnieniami językowymi. Na potwierdzenie przytoczone zostały liczne opinie respondentów przekonanych o tym, że bycie Ślązakiem polega na ,godoniu”. Dla przykładu opisano też sytuacje różnych państw i narodów, m.in. Szwajcarii i Jugosławii, gdzie miały miejsce odmienne działania narodotwórcze, w których środek komunikacji odegrał znaczącą rolę. Jednym z ważniejszych wniosków jest jednak stwierdzenie, że język nie określa identyfikacji narodowej czy etnicznej człowieka jednoznacznie, toteż nie można go rozpatrywać w izolacji - ale w kontekście innych czynników. Tymczasem mieszkańcy Śląska silnie odczuwają różnice w mowie, czyniąc z nich czynnik separujący od innych regionów Polski, a zarazem spajający Ślązaków emocjonalnie i tym samym budujący ich tożsamość. Autorka poświęca dużo miejsca na wyjaśnienie precedensowej sytuacji tego historycznego regionu, którego jedną z najbardziej charakterystycznych cech była częsta zmiana przynależności państwowej. Owa zmienność w powiązaniu z przygranicznością oraz poczuciem ,śląskiej krzywdy” (odrzuceniem i prześladowaniem zarówno przez Polaków, jak i przez Niemców) stały się według Jolanty Tambor przyczyną niestałej identyfikacji Ślązaków, której skutkiem była między innymi dwujęzyczność, a także wykształcenie specyficznego środka do komunikacji w ramach swojej grupy etnicznej. Właśnie tak - jako grupę etniczną czy etnograficzną - kwalifikuje ona Ślązaków, przyporządkowując jednocześnie ich mowie status gwary (dialektu), zbyt słabo rozwiniętej, by ubiegać się (jak np. język kaszubski) o potwierdzone ustawowo miano języ- 
ka regionalnego. Badaczka podkreśla jednak, iż mowa śląska stanowi główny czynnik identyfikacji etnicznej oraz świadomości, co potwierdza chociażby wyodrębnianie się pod nazwą „Ślązacy” (choć „Śląskość” ta różnie jest utożsamiana - zarówno jako narodowość, jak i jako element polskości, rzadziej niemieckości). Istotnym elementem rozważań w tej części jest również określenie terenu badań, którego dotyczyć będzie opis. Autorka szeroko objaśnia przyczyny zawężenia go do aglomeracji górnośląskiej, czy też - jak inaczej definiuje - obszaru dawnego Górnośląskiego Obszaru Przemysłowego. Podstawą rzetelnej analizy było bowiem wyznaczenie miejsc, w których język funkcjonowałby na zbliżonych zasadach, a gwarantowały to takie czynniki, jak podobne dzieje historyczne (istnienie w tych samych granicach), bliskość i zwartość terytorialna obszaru oraz uwarunkowania społeczno-gospodarcze (charakterystyczny typ działalności industrialnej, stopień urbanizacji, przekrój społeczny).

Rozdział drugi nosi tytuł Stan gwary ślqskiej na przełomie XX i XXI wieku i jej obraz w świadomości badaczy i użytkowników (s. 68-231). Jolanta Tambor określa w nim cele i zadania opisu gwary śląskiej. Podjęła się go z dwóch zasadniczych względów: 1) „nigdy dotąd nie został opisany w sposób systematyczny język tego terenu, opisy gwar/części dialektu na Śląsku zawsze dotyczyły wyłącznie obszarów wiejskich, zgodnie z zakorzenionym wśród dialektologów poglądem, iż gwary/dialekty występują wyłącznie na wsi”, 2) „rozpowszechnione są zarówno naukowe, jak i potoczne opinie o szybko postępującym zaniku gwar” (s. 76). Badaczka podkreśla, że odmiana językowa używana przez Ślązaków istotnie znajduje się obecnie w trudnej sytuacji, gdyż stopień jej kodyfikacji jest wręcz minimalny. Dużo miejsca poświęca na interesującą charakterystykę dotychczasowych prób opisu i normalizacji, podejmowanych niestety w większości nie przez językoznawców, lecz przez amatorów, czasami nawet niemających już na co dzień kontaktu ze swoim rodzimym językiem. Autorka wielokrotnie podkreśla też tezę, niezgodną według niej z dotychczasowymi ustaleniami dialektologicznymi, jakoby gwara śląska była językiem pochodzenia ludowego, wiejskiego, lecz w wyniku historycznego ukształtowania regionu nietypowo rozwinęła się w środowisku miejskim (ponieważ większość tych terenów znajduje się od dawna w infrastrukturze miejskiej, wiejski rodowód nie może być już brany pod uwagę). Tym samym nie można przyrównywać jej do innych odmian miejskich (np. poznańskiej czy krakowskiej), gdyż są to odrębne twory o odmiennej genezie. Jest to istotne rozróżnienie, biorąc pod uwagę fakt, iż autorka przyjmuje trzyczęściowy podział mowy Ślązaków na: gwarę śląska, śląski język miejski, czyli kod mieszany, oraz interdialekt, czyli typ ponadregionalny z wyraźnie zauważalnymi regionalizmami. Ustalenia Jolanty Tambor porządkują dotychczasowe zapa- 
trywania na regionalne odmiany polszczyzny oraz wyznaczają nowe sposoby myślenia o tej odmianie językowej. Uwagę zwraca też ciekawa konkluzja dotycząca zagrożenia, jakim jest zanikanie gwary (przyczyny tego zjawiska to zmniejszająca się liczba użytkowników oraz kurczenie się indywidualnych zasobów regionalnego języka). Szansę na przetrwanie jej cech dystynktywnych widzi $\mathrm{w}$ ich absorpcji przez odmianę mieszana, miejską. Przedmiotem zainteresowania autorki jest też wpływ wykształcenia Ślązaków oraz instytucji edukacyjnych na ich mowę. Ukazano go w sposób ambiwalentny - zarówno pozytywny (edukacja regionalna), jak i negatywny (dyskryminacja). W szczegółowym opisie wszystkich poziomów systemu językowego gwary badaczka nawiązuje do teorii przedstawionej przez Petera Trudgilla. Dotyczy ona tzw. elementów wyrazistych (saliance), które można utożsamić z cechami najtrwalszymi, czyli: najmniej podlegającymi wahaniom u użytkowników, najdłużej utrzymującymi się w ich zasobach językowych, najszybciej (najczęściej) nieświadomie pojawiającymi się u osób starających się mówić odmianą najbliższą polszczyźnie ogólnej, występującymi w cytatach ludzi z bierną znajomością gwary, wykorzystywanymi do naśladowania (także wyśmiewania) gwary. Takie ujęcie problemu sprawia, że równocześnie z charakterystyką właściwości mowy śląskiej zaznajamiamy się z relacją wzorca i faktycznej jego realizacji w aktach mowy oraz jego obrazem w świadomości użytkowników gwary. Tym samym opis jest nie tylko gruntowny, ale też przejrzysty i jasny. Warto podkreślić fakt, iż objaśnienie wyznaczników danej odmiany języka stanowi zadanie problematyczne. Okazuje się, że miano „mowa śląska” nie przez przypadek występuje w tytule recenzowanej książki. Dialekt ten nie ma zbyt wielu reprezentacji w piśmie - wynika to między innymi z przedkładania w kulturze śląskiej słowa mówionego nad pisane, ale także z trudności w oddaniu poszczególnych cech fonetycznych. Brak stałych wzorców powoduje rozległą wariantywność, którą badaczka odnotowuje nawet w różnych wypowiedziach jednego użytkownika. W analizie stanu języka konieczne było jednak odwołanie się do pewnego punktu odniesienia, tzw. wzorca abstrakcyjnego, za jaki przyjęto mowę Ślązaków z lat 1950-1970 XX wieku. Jest on w mniemaniu badanych „prawdziwą gwara” w odniesieniu do dzisiejszej „zanieczyszczonej”. Osąd ten stanowi jeden z podstawowych wyznaczników świadomości językowej użytkowników gwary. W wyniku porównania owej świadomości ze stanem faktycznym Jolanta Tambor sformułowała ciekawy wniosek, iż nie prezentuje się ona zbyt imponująco, ponieważ ogranicza się do leksyki, czyli tzw. ausdruków.

W ostatnim rozdziale - Wizerunek Ślazaka - przeszłość i teraźniejszość (s. 232-289) - opisano z kolei bardzo rozwiniętą świadomość etniczną badanych. Według autorki opiera się ona głównie na funkcjonujących wśród 
użytkowników stereotypach i autostereotypach. Przedstawione i poparte przykładami z autentycznych wypowiedzi Ślązaków zostały między innymi takie kwestie, jak: pochodzenie, zatrudnienie w kopalni, sięganie do przeszłości, cechy charakteru (gapowatość, pracowitość, czystość itp.), a także relacje (swój - obcy oraz obcy - gorol). Mimo sporej liczby tego typu wyobrażeń funkcjonujących w powszechnym mniemaniu badaczka słusznie zauważa, iż stereotyp Ślązaka nie doczekał się nigdy usankcjonowania w przysłowiach lub powiedzeniach. Zarówno cechy stereotypowe, jak i prototypowe przejawiaja się jednak czasem w języku mieszkańców Śląska. Odzwierciedlają je zazwyczaj wyrażenia oceniające i stopniujące, np. rodowity, prawdziwy, nieprawdziwy, stary.

Monografia Jolanty Tambor to publikacja wartościowa i godna uwagi. Przedstawia rzetelny, pełny i w miarę szczegółowy obraz gwary śląskiej oraz świadomości językowej jej użytkowników. Ogląd z „wewnątrz” - badacza zaangażowanego osobiście w omawianą problematykę - pozwolił uzyskać szczególnie interesujące wnioski odnoszące się do kształtowania pewnych postaw etnicznych i społecznych, znajdujących odzwierciedlenie w języku. Dodatkową zaletą jest uwzględnienie rozległych czynników zewnętrznych, tj. politycznych, kulturalnych, gospodarczych, które odegrały znaczną rolę w kształtowaniu się tej odmiany językowej. Szczególnie ważny jest w tym przypadku nie tylko ich opis, ale również analiza postaw narodowościowych $\mathrm{z}$ nimi powiązanych, mają one bowiem znaczący wpływ na kształtowanie się podejścia do języka (np. kwestii kodyfikacji, normalizacji). Mimo że badaczka korzysta z założeń socjolingwistyki, nie trzyma się utartych schematów, lecz wysuwa indywidualne tezy (np. o miejskim charakterze gwary), które następnie metodycznie udowadnia. $\mathrm{W}$ podejmowanych rozważaniach dostrzega się precyzyjny i analityczny tok myślenia. Kolejne problemy omawiane są wielopłaszczyznowo - autorka nie ogranicza się do jednej interpretacji, lecz stara się ukazać je z różnych punktów widzenia. Dotyczy to przede wszystkim zagadnień związanych z postawami Ślązaków wobec obcych (goroli) czy wobec prototypowych cech mieszkańców tamtych stron (m.in. preferowany poziom wykształcenia, pochodzenie, organizacja życia rodzinnego itp.), które to zapatrywania najczęściej zmieniają się z upływem czasu. Również opis systemu językowego gwary wydaje się wyczerpujący, szczególnie w części poświęconej leksyce. Jest ona chyba najcenniejsza pod względem poznawczym dzięki omówieniu najważniejszych i, jak się okazuje, błędnie rozumianych przez większość Polaków, wyrazów śląskich (chodzi tu o familoki, hanysa itd.). Osiagnnięcie założonych celów badawczych było możliwe dzięki umiejętnie wyzyskanym materiałom, szczególnie spontanicznym rozmowom z użytkownikami gwary. Przytoczone w dużej liczbie teksty pozwoliły na dokładne zapo- 
znanie się nie tylko z właściwościami językowymi, ale również z podstawami światopoglądu respondentów, na których podstawie możliwe było gruntowne zbadanie świadomości językowo-etnicznej Ślązaków.

Recenzowane dzieło stanowi lekturę łatwą w percepcji dzięki odpowiednio skonstruowanej budowie rozdziałów, a także prostemu i czytelnemu językowi. Do jego atrakcyjności przyczynia się również dołączona do książki płyta $\mathrm{CD}$, na której znajdują się rozmowy przeprowadzone z ankietowanymi. Mamy więc sposobność bezpośredniego zapoznania się z niemożliwymi do precyzyjnego uchwycenia na piśmie zjawiskami fonetycznymi, charakterystycznymi dla mowy Górnego Śląska. Nagrania pozwalają również na własną rękę porównać obserwacje badaczki z rzeczywistym stanem uzusu. Książka może być więc postrzegana nie tylko jako rzetelna praca naukowa, ale też jako ciekawa lektura dla każdego czytelnika zainteresowanego kulturą śląską.

Marta Kolodziejczyk 